\title{
Effect of Addition of Liquid or Dry Inoculant of Lactic Acid Bacteria Containing Different Starches on the Fermentation Quality and in Vitro Nutrient Digestibility of King Grass Silage
}

\author{
Budi Santoso ${ }^{1^{*}}$, Bambang TJahyono Hariadi ${ }^{1}$, JenI $^{2}$ \\ ${ }^{1}$ Department of Animal Science, Faculty of Animal Science, University of Papua, Manokwari, West Papua \\ 98314-Indonesia; ${ }^{2}$ Department of Biology, Faculty of Mathematics and Natural Science, University of Papua, \\ Manokwari, West Papua 98314-Indonesia.
}

\begin{abstract}
Lactic acid bacteria (LAB) are found as epiphytes on growing plants. In standing crops, however, LAB populations are low or variable, especially in the tropics. LAB inoculant must be added to improve silage quality. This study was carried out to evaluate the nutritive value and fermentation characteristics of king grass silage treated with liquid or dry LAB inoculant containing different starches as a substrate. The five treatments were as follows: (A) king grass without LAB inoculant as the control; (B) king grass $+30 \mathrm{ml}$ liquid LAB inoculant $/ \mathrm{kg}$ fresh forage; (C) king grass $+30 \mathrm{~g}$ dry LAB inoculant containing cassava starch $/ \mathrm{kg}$ fresh forage; (D) king grass $+30 \mathrm{~g}$ dry LAB inoculant containing sago starch $/ \mathrm{kg}$ fresh forage; (E) king grass $+30 \mathrm{~g}$ dry LAB inoculant containing sago and cassava starches/ $\mathrm{kg}$ fresh forage. All LAB inoculants contained more than $1.0 \times 10^{6} \mathrm{cfu} / \mathrm{g}$ fresh weight. Plastic silos, each containing about $500 \mathrm{~g}$ of silage material, were stored at room temperature $\left(28-30^{\circ} \mathrm{C}\right)$ for 30 days. Our results showed that silage treated with LAB inoculants $\mathrm{B}, \mathrm{C}, \mathrm{D}$, and $\mathrm{E}$ had lower $(P<0.01) \mathrm{pH}, \mathrm{NH}_{3}-\mathrm{N}$, and total VFA concentrations than those of the control silage (A). Silage treated with dry LAB inoculant containing cassava starch $(\mathrm{C})$ had the best fermentation quality, indicated by the highest concentrations of lactic acid and in vitro dry matter, the best organic matter digestibility, and the lowest $\mathrm{pH}$ value and butyric acid concentrations.
\end{abstract}

Keywords | Grass, Lactic acid, Ruminant, Silage, Starch

\footnotetext{
Received |August 31, 2019; Accepted | November 12, 2019; Published | November 26, 2019

*Correspondence | Budi Santoso, Department of Animal Science, Faculty of Animal Science, University of Papua, Manokwari, West Papua 98314-Indonesia; Email:b.santoso@unipa.ac.id

Citation | Santoso B, Hariadi BT, Jeni (2019). Effect of addition of liquid or dry inoculant of lactic acid bacteria containing different starches on the fermentation quality and in vitro nutrient digestibility of king grass silage. Adv. Anim. Vet. Sci. 7(12): 1127-1133.

DOI | http://dx.doi.org/10.17582/journal.aavs/2019/7.12.1127.1133

ISSN (Online) | 2307-8316; ISSN (Print) | 2309-3331
}

Copyright (C) 2019 Santoso et al. This is an open access article distributed under the Creative Commons Attribution License, which permits unrestricted use, distribution, and reproduction in any medium, provided the original work is properly cited.

\section{INTRODUCTION}

$\mathrm{E}$ nsiling is a common preservation method for moist forage crops. It is based on the anaerobic fermentation of water-soluble carbohydrates into lactic acid and volatile fatty acids (VFAs) by lactic acid bacteria (LAB). Lactic acid is commonly identified as the primary organic acid helping to reduce the $\mathrm{pH}$ of the silage. Therefore, $\mathrm{LAB}$ are the primary bacterial types utilized in inoculants (Filya et al., 2007). LAB normally grow as epiphytes; however, the population of LAB is usually low and variable in standing crops (Muck, 1990). Thus, addition of a LAB inoculant is needed to improve silage quality (Bureenok et al.,
2006). Inoculated silages with $L A B$ can result in a faster decrease in $\mathrm{pH}$, lower final $\mathrm{pH}$ values, higher lactic acid: acetic acid ratios, lower ethanol, lower ammonia nitrogen, and increased nutrient digestibility (Yahaya et al., 2004; Santoso et al., 2015; Wang et al., 2018).

Whiter and Kung (2001) reported that microbial inoculant in liquid form was more effective than in dry form. Santoso et al. (2015) concluded that silage treated with centrifuged LAB inoculant containing cassava starch had the best fermentation characteristics in king grass silage, as indicated by the highest Fleigh point compared to other silages. Jeni et al. (2010) revealed that drying the LAB inoculant by 
centrifugation produced higher bacterial viability than freeze drying. The present study was carried out to develop dry LAB inoculant preparation methods, and to evaluate the nutritive value, fermentation characteristics, and in vitro nutrient digestibility of king grass silage treated with liquid or dry LAB inoculant containing different starch.

\section{MATERIAL AND METHODS}

\section{Forage Material}

King grass (Pennisetum purpureophoides) was planted in a $20 \mathrm{~m}^{2}$ plot without fertilizer in an experimental field at the Faculty of Animal Science, University of Papua in Manokwari, Indonesia. Grass was harvested with a hand clipper after 50 days of regrowth after defoliation. The experimental field is located at $134^{\circ} 04^{\prime}$ longitude and $00^{\circ} 48^{\prime}$ latitude with a mean altitude of $110 \mathrm{~m}$ above sea level. The mean annual rainfall and temperature were $240.5 \mathrm{~mm}$ and $28.5^{\circ} \mathrm{C}$, respectively.

We prepared liquid LAB inoculant according to modified method of Bureenok et al. (2006) as used also by Santoso et al. (2012), Santoso et al. (2015). The liquid inoculant was prepared using $220 \mathrm{~g}$ of fresh king grass, which was macerated in $1000 \mathrm{ml}$ of distilled water using a high-speed blender for $4 \mathrm{~min}$. The macerated material was filtered through two layers of cheesecloth, and $600 \mathrm{ml}$ of filtrate was collected in an Erlenmeyer glass flask containing $18 \mathrm{~g}$ of glucose. The filtrate was mixed well and incubated anaerobically for $48 \mathrm{~h}$ at $30^{\circ} \mathrm{C}$.

Dry LAB inoculant was prepared according to the procedure previously described by Santoso et al. (2015). Briefly, $1000 \mathrm{ml}$ of LAB culture was divided between 4 bottles, each with a capacity of $250 \mathrm{ml}$, and centrifuged at $10,000 \mathrm{rpm}$ for $5 \mathrm{~min}$. The supernatant was removed, leaving a pellet about $10 \mathrm{ml}$ to $15 \mathrm{ml}$ in volume in each bottle. Pellet material was mixed with $250 \mathrm{~g}$ of sterilized cassava or sago starch to form the required LAB inoculant mixtures. Finally, the mixtures were added to king grass silage. Before use, the numbers of LAB in the liquid and dry inoculants were counted, following incubation for 3 days at $35{ }^{\circ} \mathrm{C}$ on de Man, Rogosa, and Sharpe agar (Bureenok et al., 2006).

\section{Silage Preparation and Treatments}

The fresh king grass was wilted at room temperature (approximately $28^{\circ} \mathrm{C}$ ) for $24 \mathrm{~h}$ and chopped into lengths of $2 \mathrm{~cm}$ to $3 \mathrm{~cm}$. The chopped grass was thoroughly mixed and representative samples obtained. The 5 treatments were as follows $(\mathrm{A})$ king grass without $\mathrm{LAB}$ inoculant as the control; (B) king grass $+30 \mathrm{ml}$ liquid LAB inoculant/ $\mathrm{kg}$ fresh forage; (C) king grass $+30 \mathrm{~g}$ dry LAB inoculant containing sago starch/kg fresh forage; (D) king grass +
$30 \mathrm{~g}$ dry LAB inoculant containing cassava starch $/ \mathrm{kg}$ fresh forage; (E) king grass $+30 \mathrm{~g}$ dry LAB inoculant containing sago and cassava starches $/ \mathrm{kg}$ fresh forage. All LAB inoculants contained more than $1.0 \times 10^{6} \mathrm{cfu} / \mathrm{g}$ fresh weight. Silage was fermented in plastic silos, each containing approximately $500 \mathrm{~g}$ (fresh weight). The silos were tied using a plastic strap and stored at room temperature $\left(25^{\circ} \mathrm{C}\right.$ to $30^{\circ} \mathrm{C}$ ). The silos were opened after 30 days of ensiling, and chemical composition, fermentation quality, and in vitro digestibility were analyzed.

\section{Chemical Analyses}

The dry matter (DM) content of silage was determined by weighing samples that had been oven dried at $65{ }^{\circ} \mathrm{C}$ for $48 \mathrm{~h}$, and the data were corrected for residual moisture at $105^{\circ} \mathrm{C}$. The crude ash content was determined after placing samples in a muffle oven for $3 \mathrm{~h}$ at $550{ }^{\circ} \mathrm{C}$. The organic matter $(\mathrm{OM})$ was calculated as weight loss upon ashing. Total nitrogen was measured using a Kjeldahl apparatus and following the procedure of the AOAC (2005). Crude protein $(\mathrm{CP})$ was calculated as total nitrogen $\times 6.25$. The neutral detergent fiber (NDF), acid detergent fiber (ADF), and acid detergent lignin (ADL) contents were determined using the procedure of Van Soest et al. (1991).

For the silage fermentation analysis, $20 \mathrm{~g}$ of silage was homogenized with $70 \mathrm{ml}$ of distilled water and stored at $4{ }^{\circ} \mathrm{C}$ for $24 \mathrm{~h}$, further homogenized for 15 min using a shaker, then filtered through two layers of cheesecloth and a Whatman No. 1542 filter paper. The filtrate was used for determination of $\mathrm{pH}$, volatile fatty acids (VFAs), lactic acid and ammonia nitrogen $\left(\mathrm{NH}_{3}-\mathrm{N}\right)$. The $\mathrm{pH}$ value was measured using a glass electrode $\mathrm{pH}$ meter (Hanna Hi 9025, Hanna Instruments Italia Srl, Villafrance Padovana, Italy). Concentrations of individual VFAs were obtained using a gas chromatograph (Varian CP-9002 GC, Shimadzu, Japan) equipped with flame ionization detector and stainless-steel column (1,500 $\mathrm{mm}$ in length $\times 3 \mathrm{~mm}$ internal diameter). The nitrogen pressure was $1.25 \mathrm{~kg} / \mathrm{cm}^{2}$. The temperatures of the injector oven, column oven and detector were $220^{\circ} \mathrm{C}, 130{ }^{\circ} \mathrm{C}$ and $220^{\circ} \mathrm{C}$, respectively. Concentrations of lactic acid and $\mathrm{NH}_{3}-\mathrm{N}$ were obtained according to the methods of Barker and Summerson (1941), and Chaney and Marbach (1962), respectively. The Fleigh points of each silage sample were calculated according to the following formula:

$$
\text { Fleigh point }=220+(2 \times D M \%-15)-(40 \times p H)
$$

Fleigh point values of between 85 and 100 denote very good quality; 60 and 80 , good quality; 55 and 60 , moderate quality; 25 and 40 , satisfactory quality and $<20$ poor quality, of no use (Ozturk et al., 2006). 


\section{IN VITRo NUTRIENT DigestibiLITY}

The in vitro digestibility of $\mathrm{DM}$, organic matter (OM) and neutral detergent fiber (NDF) following the modified method of Tilley and Terry (1963) as used by Santoso et al. (2019). For each experiment, $25 \mathrm{ml}$ of rumen fluid-buffer mixture in a $1: 4(\mathrm{v} / \mathrm{v})$ ratio was dispensed into a $100 \mathrm{ml}$ glass tube containing $250 \mathrm{mg}$ of dry sample. Triplicates of blank (no feed sample) and standard (Pangola grass) samples were included in each run. Rumen fluid was obtained from the rumens of two fistulated ongole crossbreed cattle in the morning prior to feeding. This fluid was transferred into a pre-warmed thermos flask, taken immediately to the laboratory, and filtered through four layers of cheesecloth. After outgassing to remove $\mathrm{CO}_{2}$ in the tube, corks were tightly inserted into the tubes, which were incubated in a water bath at $39^{\circ} \mathrm{C}$ for $48 \mathrm{~h}$. After $48 \mathrm{~h}$ of microbial incubation, samples were further incubated at $39{ }^{\circ} \mathrm{C}$ for $48 \mathrm{~h}$ with an acid-pepsin mixture. Finally, the contents were filtered through pre-weighed Gooch crucibles and dried at $105{ }^{\circ} \mathrm{C}$ for $24 \mathrm{~h}$. The percentage loss in weight was determined and presented as in vitro DM digestibility (IVDMD). The remaining residue was ashed at $550{ }^{\circ} \mathrm{C}$ to determine in vitro $\mathrm{OM}$ digestibility (IVOMD). The same procedure was carried out for the determination of in vitro NDF digestibility (IVNDF).

\section{Statistical Analysis}

Data on chemical composition, fermentation quality after 30 days of ensiling, and in vitro nutrient digestibility were analyzed using a completely randomized design. Analysis of variance was performed using SAS ver. 9.1 for Windows (SAS Institute Inc., Cary, NC, USA). The results are presented as the mean values and standard error of the means. Differences between treatment means were compared using Duncan's multiple range test.

\section{RESULTS AND DISCUSSION}

\section{Chemical Composition of Silages}

The moisture content of silage material plays an important role in silage fermentation, because moisture is required by $\mathrm{LAB}$ for metabolic reactions, and because it has a significant effect on the initial level and transport of oxygen during the ensilage process (Troller and Stinson, 1981). Table 1 presents the chemical composition of fresh king grass, and king grass silages, after 30 days of ensiling. The DM content of forage influences the fermentation quality of the resulting silage; optimal DM content ranges from 30 to $40 \%$ (McDonald et al., 1991). If the DM content was less than $20 \%$, the fermentation process would be dominated by Clostridium, resulting in low quality silage production (Nkosi et al., 2015). In this study, the DM content of all silages varied from 18.7 to $19.8 \%$, which was lower than the ideal value of $30 \%$ for silage as suggested by McDonald et al. (1991) and by Chamberlain and Wilkinson (1996). The $\mathrm{OM}$ and $\mathrm{CP}$ content in king grass silages was affected by the LAB inoculant. Silage treated with liquid $L A B$ inoculant (B) or dry LAB inoculant containing cassava and sago starches (E) had a higher organic matter content than control silage $(P<0.05)$. Organic matter content in all silages was slightly lower than the value of $95.3 \%$ reported by Santoso et al. (2015), but it was higher than the value of $85.83 \%$ revealed by Khota et al. (2018). Slightly lower NDF and $\mathrm{ADF}$ content was observed in silage treated with $\mathrm{LAB}$ inoculants (B, C, D and E) than in control silage. It has been reported that activity of cellulase and hemicellulase enzymes is high during ensilage (Yahaya et al., 2004). In another study, Nsereko et al. (2008) concluded that some LAB produced ferulate esterase that can increase the susceptibility of plant cell walls to enzymatic hydrolysis. Similar results have been reported in king grass silage (Santoso et al., 2011, 2015). Reduction in the structural carbohydrate content after ensiling king grass silage with added lactic acid bacteria could be due to enzymatic action, such as from hemicellulase and/or cellulase present in the original forage on cell walls (Santoso et al., 2011).

\section{Fermentation Characteristics of Silages}

Bacterial inoculants are known to improve silage fermentation and forage conservation. Most commercial inoculants contain primarily LAB. The LAB belong to a group of Gram-positive, low guanine-cytosine containing, nonmotile, non-spore forming, aerotolerant bacteria that ferment hexoses to lactic acid (Kaarel et al., 2003). The fermentation characteristics of king grass silages are shown in Table 2. Silage $\mathrm{pH}$ is one of main factors that influence the extent of fermentation and silage quality of ensiled forage, as a low $\mathrm{pH}$ ensures that the forage retains a stable form. Silage $\mathrm{pH}$ was lowest $(P<0.01)$ for $\mathrm{C}$, intermediate for $\mathrm{B}, \mathrm{D}$ and $\mathrm{E}$, and highest for the control (A) at 30 days. Lactic acid bacteria can ferment a wide source of substrates and quickly produce large amounts of lactic acid. Indeed, addition of LAB inoculant significantly increased lactic acid concentrations with a concomitant decrease in $\mathrm{pH}$. Lactic acid is the strongest of all silage acids and its presence decreases the $\mathrm{pH}$ more effectively than other VFAs (Danner et al., 2003). In the present study, only the $\mathrm{pH}$ value of silage $(\mathrm{C})$ was in the range of 4.0 to 4.5 , which was suggested by Chamberlain and Wilkinson as ideal (1996).

King grass silages including liquid or dry LAB inoculant $(B, C, D$ and $E)$ had higher lactic acid concentrations than those found in the control silage (A) $(P<0.01)$. The highest lactic acid concentration was recorded in silage with added dry LAB inoculant containing cassava starch (C), at a value of $72.1 \mathrm{~g} / \mathrm{kg}$ DM. Lactic acid concentration in silage $\mathrm{C}$ was slightly higher than in silages $\mathrm{D}$ and $\mathrm{E}$. This could be attributed to the higher amylose content of cassava 
Table 1: Chemical composition (\%) of king grass before and after an ensiling period of 30 days.

\begin{tabular}{lllllllll} 
& Before ensiling & \multicolumn{3}{c}{ Experimental Silages } & \multicolumn{3}{c}{ SEM } & P-value \\
& & A & B & C & D & E & & \\
Dry matter & 21.2 & 19.4 & 18.7 & 19.8 & 19.8 & 18.8 & 0.65 & 0.65 \\
Organic matter & 91.7 & $89.9^{\mathrm{b}}$ & $92.8^{\mathrm{a}}$ & $91.1^{\mathrm{ab}}$ & $92.1^{\mathrm{ab}}$ & $92.3^{\mathrm{a}}$ & 0.61 & 0.01 \\
Crude protein & 8.5 & $8.7^{\mathrm{b}}$ & $10.2^{\mathrm{a}}$ & $10.8^{\mathrm{a}}$ & $9.8^{\mathrm{ab}}$ & $9.4^{\mathrm{ab}}$ & 0.42 & 0.05 \\
NDF & 73.4 & 71.9 & 70.2 & 70.9 & 71.3 & 70.8 & 1.03 & 0.86 \\
ADF & 48.2 & 47.0 & 46.4 & 45.2 & 46.1 & 45.7 & 0.94 & 0.71 \\
Hemicellulose & 25.2 & 24.9 & 23.8 & 25.7 & 25.2 & 25.1 & 1.04 & 0.78
\end{tabular}

(A) king grass without LAB inoculant as the control; (B) king grass $+30 \mathrm{ml}$ liquid of epiphytic LAB inoculant $/ \mathrm{kg}$ of fresh forage; (C) king grass $+30 \mathrm{~g}$ dry inoculant of LAB containing cassava starch/kg of fresh forage; (D) king grass +30 $\mathrm{g}$ dry inoculant of LAB containing sago starch $/ \mathrm{kg}$ of fresh forage; (E) king grass $+30 \mathrm{~g}$ dry inoculant of LAB containing sago and cassava starches $/ \mathrm{kg}$ of fresh forage. Means with different superscripts in the same row differ significantly $(P<0.05)$.

Table 2: Fermentation characteristics of king grass silage treated with liquid or dry inoculant of lactic acid bacteria after 30 days of ensiling.

\begin{tabular}{|c|c|c|c|c|c|c|c|}
\hline & \multicolumn{5}{|c|}{ Experimental Silages } & \multirow[t]{2}{*}{ SEM } & \multirow[t]{2}{*}{$P$-value } \\
\hline & A & B & $\mathrm{C}$ & $\mathrm{D}$ & $\mathrm{E}$ & & \\
\hline $\mathrm{pH}$ & $5.24^{\mathrm{a}}$ & $4.65^{\mathrm{b}}$ & $4.29^{c}$ & $4.64^{\mathrm{b}}$ & $4.64^{\mathrm{b}}$ & 0.06 & 0.01 \\
\hline Lactic acid (g/kg DM) & $55.3^{\mathrm{b}}$ & $71.1^{\mathrm{a}}$ & $72.1^{\mathrm{a}}$ & $69.7^{\mathrm{a}}$ & $70.1^{\mathrm{a}}$ & 1.63 & 0.01 \\
\hline $\mathrm{NH}_{3}-\mathrm{N}(\mathrm{g} / \mathrm{kg}$ total $\mathrm{N})$ & $56.7^{\mathrm{a}}$ & $39.7^{\mathrm{b}}$ & $31.3^{\mathrm{c}}$ & $29.6^{\mathrm{c}}$ & $31.9^{c}$ & 0.71 & 0.01 \\
\hline Acetic acid (g/kg DM) & $12.0^{\mathrm{a}}$ & $10.0^{\mathrm{b}}$ & $9.8^{c}$ & $10.8^{\mathrm{ab}}$ & $11.4^{\mathrm{ab}}$ & 0.44 & 0.04 \\
\hline Propionic acid (g/kg DM) & 5.8 & 4.6 & 4.5 & 4.2 & 4.6 & 0.44 & 0.16 \\
\hline Butyric acid (g/kg DM) & $6.3^{\mathrm{a}}$ & $4.6^{\mathrm{b}}$ & $3.6^{\mathrm{b}}$ & $4.2^{\mathrm{b}}$ & $4.4^{\mathrm{b}}$ & 0.47 & 0.02 \\
\hline Total VFA (g/kg DM) & $24.1^{\mathrm{a}}$ & $19.2^{\mathrm{b}}$ & $18.0^{\mathrm{b}}$ & $19.2^{\mathrm{b}}$ & $20.5^{\mathrm{ab}}$ & 0.90 & 0.01 \\
\hline Lactic acid:Acetic acid & $4.6^{\mathrm{b}}$ & $7.1^{\mathrm{a}}$ & $7.4^{\mathrm{a}}$ & $6.5^{\mathrm{a}}$ & $6.2^{\mathrm{a}}$ & 0.32 & 0.01 \\
\hline Acetic acid:Total Acids & $0.15^{\mathrm{a}}$ & $0.11^{\mathrm{b}}$ & $0.11^{\mathrm{b}}$ & $0.12^{\mathrm{b}}$ & $0.13^{\mathrm{ab}}$ & 0.01 & 0.01 \\
\hline
\end{tabular}

(A) king grass without LAB inoculant as the control; (B) king grass $+30 \mathrm{ml}$ liquid of epiphytic LAB inoculant $/ \mathrm{kg}$ of fresh forage; (C) king grass $+30 \mathrm{~g}$ dry inoculant LAB containing cassava starch $/ \mathrm{kg}$ of fresh forage; (D) king grass $+30 \mathrm{~g}$ dry inoculant LAB containing sago starch $/ \mathrm{kg}$ of fresh forage; (E) king grass $+30 \mathrm{~g}$ dry inoculant of LAB containing sago and cassava starches $/ \mathrm{kg}$ of fresh forage. Means with different superscripts in the same row differ significantly $(P<0.05)$ and $(P<0.01)$.

starch compared to sago starch. Maherawati et al. (2011) and Kartikasari et al. (2016) reported that the amylose content of sago and cassava starches was 40.4 and $48.7 \%$, respectively. The main components of starch are amylose and amylopectin. Amylose is composed of straight chains with low molecular weight, which are easily hydrolyzed, while amylopectin has $\alpha$ (1,6)-linked branch points and a high molecular weight, making it less easily hydrolyzed. During ensiling, LAB can ferment sugar to quickly produce large amounts of lactic acid. Lactic acid in all silages in the present study varied from 55.3 to $72.1 \mathrm{~g} / \mathrm{kg} \mathrm{DM}$, and was below the 80 to $120 \mathrm{~g} / \mathrm{kg}$ ideal range recommended by Chamberlain and Wilkinson (1996). However, our lactic acid concentrations were similar to the 54.6 to $72.7 \mathrm{~g} / \mathrm{kg}$ DM reported by Santoso et al. (2015) in king grass silage treated with lactic acid bacteria.
Addition of the liquid or dry LAB inoculant to king grass silages (B, C, D and E) significantly decreased $\mathrm{NH}_{3}-\mathrm{N}$ concentration compared to the control silage (A) $(P<0.01)$. This result was consistent with that reported by Santoso et al. (2011), who found that use of fermented forage extract increased lactic acid and greatly inhibited clostridial activity, which can cause extensive protein degradation. Owens et al. (2002) reported that during ensiling, protein is degraded to peptides and free amino acids by plant proteases. In addition, degradation of amino acids to ammonia and the non-protein nitrogenous fraction is predominantly due to proteolytic clostridia. Chamberlain and Wilkinson (1996) concluded that $\mathrm{NH}_{3}-\mathrm{N}$ is an indicator of the proportion of the total $\mathrm{N}$ which has been completely degraded during ensiling. Hence, concentration of $\mathrm{NH}_{3}-\mathrm{N}$ is the best indicator of secondary fermentation. In the present study, silage 
treated with dry LAB inoculant containing cassava starch had the lowest $\mathrm{NH}_{3}-\mathrm{N}$. McDonald et al. (1991) reported that a low $\mathrm{pH}$ inhibits protein degradation in silage. In the present study, the low $\mathrm{pH}$ values in $\mathrm{B}, \mathrm{C} \mathrm{D}$ and $\mathrm{E}$ silages prevented protein degradation. Whiter and Kung (2001) stated that homofermentative LAB reduce proteolysis and deamination of silage through a more rapid fall in $\mathrm{pH}$. Concentrations of $\mathrm{NH}_{3}-\mathrm{N}$ in $\mathrm{B}, \mathrm{C}, \mathrm{D}$ and $\mathrm{E}$ silages in this study varied from 29.6 to $39.7 \mathrm{~g} / \mathrm{kg}$ total $\mathrm{N}$. This is below the ceiling of $50 \mathrm{~g} / \mathrm{kg}$ total $\mathrm{N}$ for optimally preserved silage proposed by Chamberlain and Wilkinson (1996)

The effect of the addition of LAB inoculant on VFA concentrations in king grass silage is shown in Table 2. The addition of LAB inoculant significantly decreased concentrations of acetic acid and butyric acid $(P<0.05)$, and total VFA $(P<0.01)$, while increasing the lactic acid: acetic acid ratio $(P<0.01)$. Silage $C$ had the lowest acetic acid, butyric acid and total VFA concentrations. The acetic acid: total fermentation acids ratio in all silages varied between 0.11 and 0.15 which is considerably less than the recommended maximum value of 0.20 (Lima et al., 2011). Acetic acid is produced from carbohydrate fermentation by enterobacteria. Acetic acid, however, is a relatively minor end product, and the enterobacteria are therefore not desirable in silage fermentation. Total VFA concentration was lower in silages $\mathrm{B}, \mathrm{C}$ and $\mathrm{D}$ than in silages $\mathrm{A}$ and $\mathrm{E}(P<0.01)$. Silage $C$ had slightly lower total VFA concentration than silages $\mathrm{B}$ or $\mathrm{D}$. These results indicate that the fermentation occurring in silage $\mathrm{C}$ was more efficient than that in the other silages. Chamberlain and Wilkinson (1996) stated that the VFAs comprise acetic acid, propionic acid, butyric acid, and other acids. The production of these acids results from inefficient fermentation or secondary fermentation of lactic acid to butyric acid and degradation of amino acids to ammonia with the production of acetic acid from the carbon skeleton of the amino acid.

A ratio of lactic acid to acetic acid of more than 2:1 indicates a homolactic dominant fermentation (Zhang et al., 2010). As shown in Table 2, ratios in all silages exceeded 2:1. However, the ratios in silages with addition of LAB inoculants were higher than that in the control silage. This result suggests that fermentation where LAB inoculants have been added is dominated more by homofermentative bacteria such as L. plantarum.

Fleigh point is an indicator used to assess silage fermentation quality and is based on dry matter content and silage $\mathrm{pH}$ value. The addition of liquid and dry LAB inoculants increased the Fleigh point of king grass silage $(P<0.01)$ (Figure 1). Based on the classification by Ozturk et al. (2006), silage C was of good quality, silages B, D and $\mathrm{E}$ were of moderate quality, and silage $\mathrm{A}$ was of satisfactory quality. The Fleigh point of all silages was lower to the
72.83 in an alfalfa-maize silage mixture reported by Ozturk et al. (2006) and the value reported in agricultural wastes-based complete feed silage, which varied from 87.3 to 113.0 (Santoso et al., 2019).

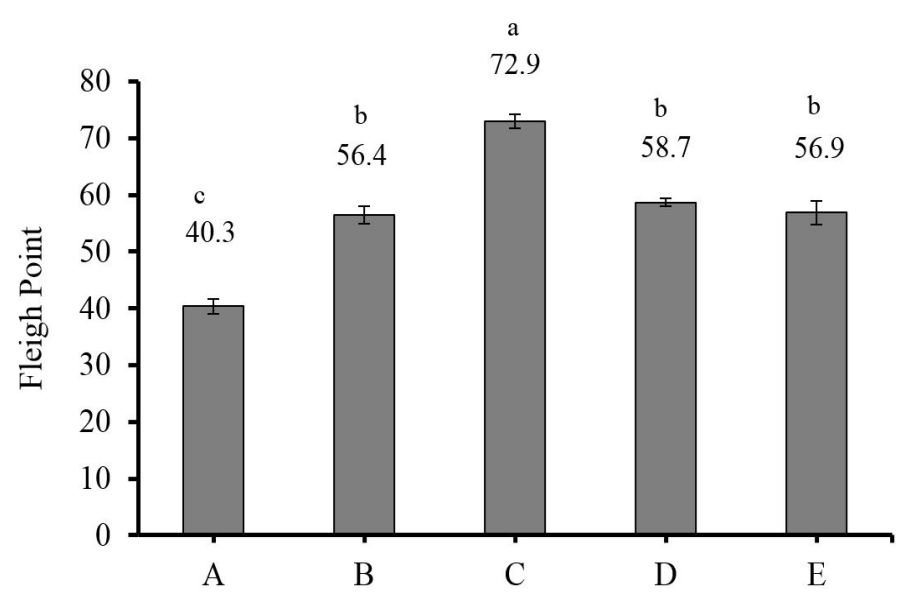

Figure 1: Fleigh point of 30-day king grass silage. (A) king grass without LAB inoculant as the control; (B) king grass $+30 \mathrm{ml}$ liquid of epiphytic LAB inoculant $/ \mathrm{kg}$ of fresh forage; (C) king grass + $30 \mathrm{~g}$ dry inoculant of LAB containing cassava starch $/ \mathrm{kg}$ of fresh forage; (D) king grass $+30 \mathrm{~g}$ dry inoculant of LAB containing sago starch $/ \mathrm{kg}$ of fresh forage; (E) king grass $+30 \mathrm{~g}$ dry inoculant of LAB containing sago and cassava starches $/ \mathrm{kg}$ of fresh forage. ( $\mathrm{n}$ $=3$, bars indicate standard error of the means). Means with different small letters show significant difference among treatments at $P<0.01$.

\section{IN VITRo NUTRIENTS DigeSTIBILITY}

In vitro digestibility reflects the degree of digestion of substrates by microorganisms in an artificial environment, where rumen conditions are simulated in a test tube. The in vitro digestibilities of components of king grass silage at 30 days of ensiling are shown in Table 3. The addition of liquid or dry LAB inoculant in silages $\mathrm{B}, \mathrm{C}, \mathrm{D}$ and $\mathrm{E}$ increased IVDMD $(P<0.05)$ and IVOMD $(P<0.01)$ when compared to the control silage (A). Among silages with addition of dry LAB inoculant, the silage with added dry LAB inoculant containing cassava starch $(C)$ had the highest IVDMD and IVOMD. The addition of liquid or dry LAB inoculant in silages B, C, D and E increased IVDMD by 5.3, 6.7, 6.7 and 5.9\% respectively, as well as increasing IVOMD by $6.7,8.3,6.5$ and $5.2 \%$ respectively, in all cases as compared with the relevant result for the control silage. This could be attributed to the differences in fiber content of those silages. Silage A had higher fiber contents (NDF and $\mathrm{ADF}$ ) than silages $\mathrm{B}, \mathrm{C}, \mathrm{D}$ and $\mathrm{E}$, as shown in Table 1. Our findings are in agreement with those of Santoso et al. (2015), that IVDMD and IVOMD tended to increase in king grass silage treated with LAB inoculant compared to control silage. Furthermore, addition of LAB inoculant significantly increased IVNDFD. Higher IVNDFD appears to be related to the physical characteristics of the 
forage, especially the NDF and ADF contents. Low NDF and $\mathrm{ADF}$ contents in forage resulted in a rapid increase in digestibility of DM, OM and NDF. Silages $\mathrm{C}$ and $\mathrm{E}$ had higher IVNDFD than other silages $(P<0.05)$. The higher IVNDFD in both $\mathrm{C}$ and $\mathrm{E}$ silages could be due to their lower ADF contents as shown in Table 1 . These results confirm that addition of dry inoculant containing cassava or sago starch could improve in vitro nutrient digestibility.

Table 3: In vitro nutrient digestibility (\%) of king grass silage treated with liquid or dry inoculant of lactic acid bacteria after 30 days of ensiling.

\begin{tabular}{lllllllll} 
& \multicolumn{4}{c}{ Experimental Silages } & \multicolumn{3}{c}{ SEM P- } \\
& A & B & C & D & E & & value \\
IVDMD & $52.6^{\mathrm{b}}$ & $55.4^{\mathrm{a}}$ & $56.1^{\mathrm{a}}$ & $56.1^{\mathrm{a}}$ & $55.7^{\mathrm{a}}$ & 0.70 & 0.02 \\
IVOMD & $55.4^{\mathrm{b}}$ & $59.2^{\mathrm{a}}$ & $60.4^{\mathrm{a}}$ & $59.4^{\mathrm{a}}$ & $58.6^{\mathrm{ab}}$ & 0.48 & 0.01 \\
IVNDFD & $39.8^{\mathrm{b}}$ & $41.3^{\mathrm{ab}}$ & $41.9^{\mathrm{a}}$ & $41.0^{\mathrm{ab}}$ & $42.2^{\mathrm{a}}$ & 0.42 & 0.04 \\
\hline
\end{tabular}

(A) king grass without LAB inoculant as the control; (B) king grass $+30 \mathrm{ml}$ liquid of epiphytic LAB inoculant $/ \mathrm{kg}$ of fresh forage; (C) king grass $+30 \mathrm{~g}$ dry inoculant of $\mathrm{LAB}$ containing cassava starch $/ \mathrm{kg}$ of fresh forage; (D) king grass $+30 \mathrm{~g}$ dry inoculant of LAB containing sago starch $/ \mathrm{kg}$ of fresh forage; (E) king grass $+30 \mathrm{~g}$ dry inoculant of LAB containing sago and cassava starches $/ \mathrm{kg}$ of fresh forage. Means with different superscripts in the same row differ significantly $(P<0.05)$ and $(P<0.01)$.

\section{CONCLUSION}

Addition of liquid and dry LAB inoculant was effective in improving silage fermentation and promoting the digestibility of king grass. Silage with the addition of dry LAB inoculant containing cassava starch had the best fermentation quality indicated by lowest $\mathrm{pH}$ value and highest Fleigh point.

\section{ACKNOWLEDGEMENT}

This study was financially supported by the Indonesian Ministry of Education and Culture through its "Hibah Bersaing" program.

\section{CONFLICT OF INTEREST}

There is no conflict of interest.

\section{AUTHOR CONTRIBUTION}

All authors contributed equally.

\section{REFERENCES}

-AOAC (Association of Official Analytical Chemists) (2005). Official Methods of Analysis. $17^{\text {th }}$ Ed.Washington: AOAC International.

- Barker SB, Summerson WH (1941). The colorimetric determination of lactic acid in biology material. J. Biol. Chem. 138:535-554.

-Bureenok S, Namihira T, Mizumachi S, Kawamoto Y, Nakada $T$ (2006). The effect of epiphytic lactic acid bacteria with or without different byproduct from defatted rice bran and green tea waste on napiergrass (Pennisetum purpureum Shumach) silage fermentation. J. Sci. Food Agric. 86: 1073-1077. https://doi.org/10.1002/jsfa.2458

-Chamberlain AT, Wilkinson JM (1996). Feeding the Dairy Cow. Chalcombe Publications, Lincoln, UK.

- Chaney AL, Marbach EP (1962). Modified reagents for determination of urea and ammonia. Clin. Chem. 8: 130132.

- Chen L, Ren A, Zhou C, Tan Z (2017). Effects of Lactobacillus acidophilus supplementation for improving in vitro rumen fermentation characteristics of cereal straws. Ital. J. Anim. Sci. 16: 52-60. https://doi.org/10.1080/182805 1X.2016.1262753

- Danner H, Holzer M, Mayrhuber E, Braun R (2003). Acetic acid increases stability of silage under aerobic conditions. Appl. Environ. Microbiol. 69: 562-567. https://doi.org/10.1128/ AEM.69.1.562-567.2003

-Ebrahimi M, Rajion MA, Goh YM, Farjam AS, Sazili AQ, Schonewille JT (2014). The Effects of adding lactic acid bacteria and cellulase in oil palm (Elais guineensis Jacq.) frond silages on fermentation quality, chemical composition and in vitro digestibility. Ital. J. Anim. Sci. 13:557-562. https://doi.org/10.4081/ijas.2014.3358

- Filya I, Muck RE, Contreras-Govea FE (2007). Inoculant effects on alfalfa silage: fermentation products and nutritive value. J. Dairy Sci. 90: 5108-5114. https://doi.org/10.3168/ jds.2006-877

-Jeni, Hamim, Tjahjoleksono A, Soemantri ID (2010). Viabilitas dan efektivitas pupuk hayati dari beberapa teknik pengeringan dan lama penyimpanan. In: Supena (ed), Prosiding Seminar Nasional Sains III, FMIPA IPB Bogor, 13 November 2010.

-Kaarel A, Kak S, Laht T, Paalma T (2003). The effect of temperature and $\mathrm{pH}$ on the growth of lactic acid bacteria: a pH-auxostat study. Int. J. Food Microbiol. 85: 171-183. https://doi.org/10.1016/S0168-1605(02)00537-8

- Kartikasari SN, Sari P, Subagio A (2016). Characterization of chemical properties, amylograpic profiles (RVA) and granular morphology (SEM) of biologically modified cassava starch. J. Agroteknologi. 10: 12-24.

- Khota W, Pholsen S, Higgs D, Cai Y (2018). Comparative analysis of silage fermentation and in vitro digestibility of tropical grass prepared with Acremonium and Tricoderma species producing cellulases. Asian-Aust. J. Anim. Sci. 31: 1913-1922. https://doi.org/10.5713/ajas.18.0083

-Kizilsimsek M, Schmidt RJ, Kung LJr (2007). Effects of a mixture of lactic Acid bacteria applied as a freeze-dried or fresh culture on the fermentation of alfalfa silage. J. Dairy Sci. 90: 5698-5705. https://doi.org/10.3168/jds.2007-0448

- Lima R, Díaz RF, Castro A, Hoedtke S, Fievez V (2011). Multifactorial models to asses responses to sorghum proportion, molasses and bacterial inoculant on in vitro 
quality of sorghum-soybean silages. Anim. Feed Sci. Tech. 164: 161-173. https://doi.org/10.1016/j. anifeedsci.2011.01.008

- Maherawati, Lestari RB, Haryadi (2011). Characteristics of starch from West Kalimantan sago trunks at different growth stages. Agritech. 31: 9-13.

- McDonald P, Henderson A, Heron S (1991). The Biochemistry of Silage. Marlow, UK: Chalcombe Publications. https://doi. org/10.1021/bi00228a029

- Muck RE (1990). Prediction of lactic acid bacteria numbers on lucerne. Grass Forage Sci. 45: 273-280. https://doi. org/10.1111/j.1365-2494.1990.tb01950.x

- Nishino N,Uchida S (1999). Laboratory evaluation of previously fermented juice as a fermentation stimulant for Lucerne silage. J. Sci. Food Agric. 79: 1285-1288. https://doi.org/10.1002/ (SICI)1097-0010(19990715)79:10<1285::AID JSFA362>3.0.CO;2-M

- Nkosi BD, Meeske R, Langa T, Motiang MD, Mutavhatsindi TF (2015). The influence of ensiling potato hash waste with enzyme/bacterial inoculant mixtures on the fermentation characteristics, aerobic stability and nutrient digestion of the resultant silages by rams. Small Rum. Res. 127: 2835. https:// doi.org/10.1016/j.smallrumres.2015.04.013

- Nsereko VL, Smiley BK, Rutherford WM, Spielbauer A, Forrester KJ, Hettinger GH, Harman EK, Harman BR (2008). Influence of inoculating forage with lactic acid bacteria strains that produce ferulate esterase on ensilage and ruminal degradation of fiber. Anim. Feed Sci. Technol. 145: 122-135. https://doi.org/10.1016/j.anifeedsci.2007.06.039

- Owens VN, Albrecht KA, Muck RE (2002). Protein degradation and fermentation characteristics of unwilted red clover and alfalfa silage harvested at various times during the day. Grass Forage Sci. 57: 329-341. https:// doi.org/10.1046/j.1365-2494.2002.00333.x

- Ozturk D, Kizilsimsek M, Kamalak A, Canbolat O, Ozkan CO (2006). Effects of ensiling alfalfa with whole-crop maize on the chemical composition and nutritive value of silage mixtures. Asian-Aust. J. Anim. Sci. 19: 526-532. https://doi. org/10.5713/ajas.2006.526

-Santoso B, Hariadi BTj, Manik H, Abubakar H (2011). Silage quality of king grass (Pennisetum purpureophoides) treated with epiphytic lactic acid bacteria and tannin of acacia. Med. Pet. 34: 140-145. https://doi.org/10.5398/ medpet.2011.34.2.140

-Santoso B, B. Hariadi BTj, Alimuddin, Seseray DY (2012). Fermentation characteristics of rice crop residue-based silage treated by epiphytic and commercial LAB. Med. Pet. 35: 60-66. https://doi.org/10.5398/medpet.2012.35.1.60

-Santoso B, Hariadi BTj, Jeni (2015). Fermentation quality of king grass silage treated with liquid or dried inoculant of lactic acid bacteria. J. Indonesian Trop. Anim. Agric. 40: 208214. https://doi.org/10.14710/jitaa.40.4.208-214

-Santoso B, Widayati, TW, Hariadi BTJ (2019). The fermentation quality and in vitro nutrient digestibility of agricultural waste based-complete feed silage with different composition of oil palm frond and rice crop residue. Adv. Anim. Vet. Sci. 7(8): 621-628. https://doi.org/10.17582/ journal.aavs/2019/7.8.621.628

-Tilley JM, Terry RA (1963). A two stage technique for the in vitro digestion of forage crops. J. Br. Grassland Soc. 18: 104111. https://doi.org/10.1111/j.1365-2494.1963.tb00335.x

- Troller JA, Stinson JV (1981). Moisture requirements for growth and metabolite production by lactic acid bacteria. Appl. Environ. Microbiol. 42: 682-687.

- Van Soest PJ, Robertson JB, Lewis BA (1991). Methods for dietary fiber, neutral detergent fiber, and nonstarch polysaccharides in relation to animal nutrition. J. Dairy Sci. 74: 3583-3597. https://doi.org/10.3168/jds.S00220302(91)78551-2

-Wang S, Li J, Dong Z, Chen L, Shao T (2018). Effect of microbial inoculants on the fermentation characteristics, nutritive value, and in vitro digestibility of various forages. Anim. J. 00:1-11.

-Weinberg ZG, Muck RE, Weimer PJ, Chen Y, Gamburg M (2004). Lactic acid bacteria used in inoculants for silage as a probiotics for ruminants. Appl. Biochem. Biotech. 118: 1-10 .https://doi.org/10.1385/ABAB:118:1-3:001

-Whiter AG, Kung LJr (2001). The effect of a dry or liquid application of Lactobacillus plantarum MTD1 on the fermentation of Alfalfa silage. J. Dairy Sci. 84: 2195-2202. https://doi.org/10.3168/jds.S0022-0302(01)74666-8

- Yahaya MS, Goto M, Yimiti W, Smerjai B, Kuwamoto Y (2004). Evaluation of fermentation quality of a tropical and temperate forage crops ensiled with additives of fermented juice of epiphytic lactic acid bacteria (FJLB). AsianAust. J. Anim. Sci. 17: 942-946. https://doi.org/10.5713/ ajas.2004.942

-Zhang YG,Xin HS,HuaJL (2010). Effects of treating wholeplant or chopped rice straw silage with different levels of lactic acid bacteria on silage fermentation and nutritive value for lactating Holsteins. Asian-Aust. J. Anim. Sci. 23(12): 16011607. https://doi.org/10.5713/ajas.2010.10082 